\title{
ENTRE EVASÃO E ABDICAÇÃO: O EXTREMISMO E O EXCESSO EM COMIGO E NO DIÁRIO ÍNTIMO, DE MANUEL LARANJEIRA
}

Rui Sousa ${ }^{1}$

RESUMO: Neste ensaio, procuraremos analisar de que modo o poeta português Manuel Laranjeira, nos poemas recolhidos em Comigo (1912) e no Diário Intimo (1957), desenvolve um tratamento do excesso de acordo com uma bipolarização constante entre um desejo de evasão com cambiantes blasfemas, por se identificar com o desejo de se equiparar a Deus, e uma consciência pessimista do desengano e da impossibilidade de fazer coincidir a existência com esse ideal artístico.

PALAVRAS-CHAVE: Manuel Laranjeira; Excesso; Extremismo; Bipolarização.

\section{Between Evasion and Abdication: Extremism and Excess in Manuel Laranjeira's} Comigo and Diário Íntimo

ABSTRACT: In this paper, we will try to analyze how the Portuguese poet Manuel Laranjeira, in the poems collected in Comigo (1912) and in the Diárióntimo (1957), develops a treatment of excess, according to a polarization between a constant desire to escape, with blasphemous suggestions in the form of a desire to equate God, and a pessimistic awareness of disillusionment and inability to make the existence coincide with this artistic ideal.

KEY-WORDS: Manuel Laranjeira; Excess; Extremism; Bipolarization.

Em 1912, pouco antes do suicídio que de alguma forma extremou sua incapacidade de conviver consigo e com o mundo que contemplava sempre mergulhado num tédio profundo, Manuel Laranjeira publica a sua recolha de poemas, Comigo, que, como veremos, concentra os principais temas do seu pensamento permanentemente voltado para si, enquanto espetáculo de degradação. Em 1957, Alberto de Serpa deu a conhecer outra importante peça desse discurso depressivamente obsessivo sobre o eu atormentado, cindido entre uma tendência ascensional, que o isolava de todos os outros e o identificava com um deus, e um olhar frio e por vezes cínico e cruel sobre a sua vida e, por contaminação, a existência coletiva, quer de Portugal, quer da Humanidade. É a partir destas duas obras de Manuel Laranjeira, geracionalmente contemporâneo do Decadentismo

\footnotetext{
${ }^{1}$ Investigador integrado do CLEPUL - Centro de Literaturas e Culturas Lusófonas e Europeias da Faculdade de Letras de Lisboa. Bolsista de doutoramento da FCT, frequenta na mesma faculdade o doutoramento em Estudos Românicos.
} 
e de outros movimentos finisseculares ${ }^{2}$ mas também dos modernistas portugueses ${ }^{3}$, que procuraremos analisar o excesso de radicalismo dessa polaridade, de algum modo afim daquela subjetiva crise de impossibilidades a que Mário de Sá-Carneiro daria expressão em poemas como “Quasi”, publicado em Dispersão, de 1914.

Para a análise desta cisão entre saciedade e irremediável insatisfação e desejo de um absoluto que não é humanamente alcançável, nem mesmo na transfiguração da vida em arte, a nossa reflexão terá em conta algumas considerações relevantes do filósofo espanhol Ortega y Gasset no texto "Sobre el extremismo como forma de vida", uma das lições do conjunto En torno a Galileo, de 1947. Quanto a nós, a definição de "extremismo" que Ortega elabora neste texto aproxima-se bastante do estado de espírito de Manuel Laranjeira, que críticos como Bernard Martocq, José Carlos Seabra Pereira ou Nuno Júdice têm identificado como intrínseco ao essencial pessimismo com que o poeta encarava a vida. Considera Ortega a respeito da situação de desencanto que faz com que seja possível a um ser humano desgostar-se da própria vida:

Es evidente que el hombrepuedellegar a encontrarseen una situación tal que al tener que hacer algo para vivir - ya sabemos que viver estener que hacer algo - no se le ocorre ningúnquehacer que leparezcasatisfactorio, a nada que parezca suficiente leincitan las cosas de su horizonte material y social ni las ideas de su horizonte intelectual. Seguira haciendo esto o lo otro, pero lo hará como un autómata, sinsolidarizarsecon sus actos, que considera nulos, inválidos, sin sentido. Surge entoncesun asco indomable al mundo y al vivir, que se presenta con carácter puramente negativo (ORTEGA Y GASSET, 1983, p.107).

\footnotetext{
${ }^{2}$ Embora nos pareça de sublinhar a singularidade do seu caso autoral e humano, a influência do paradigma decadentista na expressão poética das temáticas a ele associadas não deve ser menorizada. Uma leitura atenta de estudos como Decadentismo e Simbolismo na Poesia Portuguesa, de José Carlos Seabra Pereira, permite-nos perceber as raízes desse imaginário que apresenta o Poeta como um ente cindido, debatendo-se com sugestões de superioridade devida à sua sensibilidade excepcional, a atracção pela Arte enquanto forma de compensar a existência entendida como insuficiente e o consequente isolamento esteticista, uma inquietude pessimista e a atracção pela morte, pelas ruínas, pela efemeridade do amor e os desvios e tons viciosos da sexualidade. Num trabalho dedicado justamente a Manuel Laranjeira, Seabra Pereira observa que a obra do poeta "constitui interessante peça no jogo das tendências estético-ideológicas epocais", acentuando a diferença da poesia de Comigo, assim como do Diário Íntimo e das Cartas, relativamente a publicações do autor anteriores a 1912, exibindo "uma lírica fundamentalmente decadentista em estratificação tensional com veios de reacção vitalista que lavra crescentemente no início do séc. XX” (PEREIRA, 1979, p.43-44).

${ }^{3}$ Amigo de Amadeo de Souza Cardoso, a sua recolha de poemas data do mesmo ano em que Fernando Pessoa fez a sua primeira publicação em $A$ Águia, revista em cujo primeiro número se republicara, nas páginas inaugurais, o texto de Laranjeira "Os homens superiores na selecção social".
} 
Face a esta situação, o homem "verdaderamente desesperado" procura recolher-se a um determinado ponto da existência como resposta ao desencontro produzido pela "excessiva riqueza de la vida - los muchos saberes e ninguno suficiente, los muchosapetitos y placeresposibles, pero ningunoplenario, el demasiado amontonamiento de quehaceresforzosos, pero ningunocon sentido absoluto satisfactorio" (ORTEGA Y GASSET, 1983, p.108). É nessa negação de todos os aspetos da vida, exceto uma que se adota como ponto isolado, que se constitui a identidade extremista, dominada pelo exaspero e por um impulso de exclusão contrário ao aspecto integrador da cultura. Constitui-se, então, uma visão do mundo específica deste sujeito:

El hombre, pues, que se retrae a esa sola cuestión la exagera, exacerba y exaspera, la saca de quicio, esdecir, de su lugar, renuncia a aceptarauténticamente la vida segúnes y, por una ficción íntima que le inspira sudésesperación, la reduce a un extremo, se instala enél y hace el extremismo. Y desde élcombatirá el resto enorme de lo humano, negará la ciencia, la moral, el orden, la verdad, etcétera, etc. (ORTEGA Y GASSET, 1983, p.112).

São ainda de assinalar, neste contexto, duas outras observações de Ortega: a aproximação entre este tipo de vivência e as épocas consideradas de crise, nas quais domina a inautenticidade, o equívoco e um certo histrionismo (ORTEGA Y GASSET, 1983, p.114) e a leitura desse tipo de impotência à luz de uma absoluta descrença no próprio sentido da vida e da capacidade dos homens em orientarem o seu rumo:

De nada vale la justificación relativa que enrelación unos conotrospuedantener los actos de mi vida si el hecho total de vivierno latiene. Sería preciso que algo de lo que hacemos al vivirtengaun valor absoluto. Ahorabien, nada hayen el interior de nuestra vida que parezca plenamente satisfactorio y por símismo se justifique. Nuestraexistenciaesensímismaunvacío de sentido, una extrañarealidad que consiste en ser algo que, en definitiva, es nada, es la nada siendo, es la pretensión de algo positivo que se queda en pura pretensiónfallida (ORTEGA Y GASSET, 1983, p.118).

É esta precisamente a lacuna de que sofre Manuel Laranjeira, da qual o sujeito literário que se expressa em Comigo e em Diário Íntimo será uma projeção perfeita: estamos sempre perante um homem incapaz de conduzir a sua vida num rumo satisfatório, justamente por ter deixado de encontrar um sentido coeso para a existência, que opta então pelo isolamento fornecido pela criação de um mundo artístico alternativo e compensador, que acabará, contudo, também por ser percecionado como fracasso, encaminhando-se para 
esse "grau de devastação raras vezes expresso pela literatura finissecular" (PEREIRA, 1979, p.52) a cujos efeitos não escapará nem o mundo exterior nem as soluções artísticas que o sujeito lhe contrapõe como alternativas.

Como observou Nuno Júdice em As Máscaras do poema, a incapacidade de viver convenientemente a vida depende muito da relação incontrolável com essa personagem espelhada do eu:

há nele uma consciência hipercrítica que o impede de superar a decepção e o desgosto que esse real lhe provoca. O autor é uma vítima da acção que inventa para dar forma ao drama da sua vida; e não consegue libertar-se dos condicionamentos do personagem para ter um domínio das situações (JÚDICE, 1998, p.101-102).

Tudo se processa, como defende Júdice, como se Manuel Laranjeira tivesse renunciado a viver a sua existência sem ter de fazer de cada momento um episódio de um interminável drama, no qual ele próprio e todas as pessoas com quem se relaciona representam um determinado papel, que vai sendo comentado no Diário. É uma expressão dessa outra vertente excessiva que, coincidindo parcialmente com o impulso icárico muito evidente na poesia de Mário de Sá-Carneiro, deriva da "ambição de ser Deus [que] não é mais do que o sonho de ascender à categoria do Autor, que domina o destino dos personagens" (JÚDICE, 1998, p.102) e o seu próprio percurso, enquanto encenação de uma determinada expressão decadente e irreversível da doença, do pessimismo, do tédio e da indiferença perante o destino dos homens e do mundo. Seabra Pereira integra esta questão num entendimento epocal coincidente com a poética decadentista finissecular que conhecera particular expansão na última década de Oitocentos, período em que Laranjeira terá contactado de perto com o tom decadente, anunciador de um esgotamento civilizacional e do desejo de fuga esteticista, e com as reivindicações nefelibatas de originalidade de Eugénio de Castro, António Nobre, Camilo Pessanha, Raul Brandão, João Barreira, entre outros, com os quais dialogará na produção do seu registo particular:

Muito de acordo com a proximidade em que a lírica do nosso Decadentismo finissecular se mantém relativamente à tenaz tradição de sub-romantismo sentimental e expressivo, Comigo parece privilegiar por vezes o registo amoroso da contingência dos seres e da fugacidade da ventura, do carácter inconsumável das aspirações humanas (...). Mas a obra não se diminui reducionistamente nesse registo, pois faz dele um mero factor menor do reconhecimento daqueles princípios filosófico-morais. O desengano reina para além do domínio afectivo e afirma-se lei irrevogável da existência (...) (PEREIRA, 1979, p.51). 
Perfeitamente integrado no seu tempo em termos culturais, filosóficos e vivenciais, Manuel Laranjeira parece ecoar também as considerações que, em 1951, Albert Camus dedicou ao fenômeno oitocentista do dandismo:

Até então, a criatura recebia do Criador a sua coerência. A partir do momento em que ela consagra a sua ruptura em relação a Deus, ei-lo entregue aos instantes, aos dias que passam, à sensibilidade dispersa. Forçoso se torna portanto que ela emende a mão. $\mathrm{O}$ dândi recompõe-se, procura conferir a si próprio uma unidade por meio da própria força da recusa. Criatura dispersa, como pessoa privada de regras que é, o dândi será coerente como personagem. Mas uma personagem pressupõe um público; o dândi não pode alicerçar-se sem adoptar uma atitude de oposição. Não pode assegurar-se da sua existência se a não reencontrar no rosto dos outros. Os outros são o espelho. Espelho rapidamente embaciado, é certo, pois a capacidade de atenção do homem é limitada. Tem de ser constantemente despertada, esporeada pela provocação. Por isso, o dândi se vê constantemente forçado a espantar os outros. A sua vocação consiste na singularidade; o seu aperfeiçoamento, na excedência (CAMUS, 2003, p.68).

Se não é evidente que Laranjeira adote a iconografia excessiva da indumentária dos dândis, estão contudo presentes na sua obra dois elementos fulcrais nesta observação do autor de $O$ Homem revoltado: a relação turbulenta com o Criador, evidente, quer no desejo de ascensão a um patamar divino a partir do qual tudo poderia observar e organizar, na liberdade orgulhosa da solidão, quer numa tendência blasfema típica do desencontro com o sentido da existência, herdeiro de um certo niilismo bebido sobretudo em Schopenhauer e em Nietzsche; e a persistência de uma relação conflituante entre o sujeito e as outras personagens com que se cruza, que denigre constantemente e que, na intimidade do Diário, afirma desprezar mas que não consegue deixar de procurar ou de ter em conta, porque delas depende o prolongar do ideal de superioridade e, noutro sentido, da incapacidade de, como todos os outros, manter qualquer tipo de ilusão ou crença.

O primeiro poema de Comigo, cujo título se alarga ao da recolha mas que apresenta o significativo subtítulo "Diálogo com a minha alma", expressará de modo exemplar as aparentes cisões do sujeito, assim como a tendência final para a aproximação numa atitude desistente. Constituindo-se, de acordo com o subtítulo, como um diálogo entre o eu e a sua alma, pessimista e suficientemente convincente para, no final, anular todos os argumentos com que o eu tenta contrariar esse espírito negativo, este longo poema é o espelho desse 
sujeito ferido por uma megalomania fracassada e pela desilusão a que ela conduziu. Tanto mais que esse eu que se dirige à alma, mesmo antes da intervenção desta, evidencia já uma descrença camuflada pelo isolamento num determinado ideal - conforme sugere Ortega que coincide com a adoção de uma mentira:

Pobre alma desiludida, /teu mal é não esquecer / que tudo falha na vida... //Mas ouve, alma: pra viver /e ser feliz é preciso / fitar a mentira e crer, // como alguém que sem juízo / olha para a terra e a vê / convertida em paraíso... //Um coração que não crê / na mentira cegamente, /coração feliz não é (LARANJEIRA, 1993, p.158).

Este relativo otimismo com que se invetiva a alma é, portanto, gerado não por uma crença verdadeira nas possibilidades da vida, mas por uma tentativa forçada de a encarar com olhos transfiguradores que a mascarem, iludindo o sujeito. É um exemplo perfeito de acomodamento a um compartimento da existência - a ilusão paradisíaca das coisas - que anula todos os outros e que, caso desmontado, também não terá como subsistir:

é que vemos, na verdade, / que destruindo a mentira, /se mata a felicidade, //e que somente existira / no desejo - essa ventura, / ... e a verdade a destruíra. //Quem a verdade procura, /busca a sua perdição, /busca a sua desventura. //Só se vive de ilusão; /a verdade é venenosa, / envenena o coração (LARANJEIRA, 1993, p.158-159).

Essa verdade - identificada com a "febre de saber" (p.159) e com a "sede insofrida" (p.160) - é mais uma das sugestões de como o conhecimento da realidade pode ser trágico para quem o procura demasiado, concordante com mitos clássicos como os de Ícaro ou Prometeu e representações modernas como as de Fausto e de Frankenstein. Este sujeito defende a adoção de um ideal de abdicação que passa por ascender a um patamar "acima da vida impura" que deve ser ignorada, "como um condor que passa / sobre a terra e nem a fita” (p.161). Mas mesmo nesse voo entendido como refúgio orgulhoso de um ente superior está bem presente a mancha do fracasso e da tristeza, pois é típico de "um deus que entristece /vendo a sua Obra falhar...” (p.161).

A alma, respondendo a essas sugestões, evidencia a lucidez necessária para desmontar essa estrutura de engano consentido, recusando uma existência baseada na impossibilidade de encontro com a ilusão:

Perdida a fé que consiste / em deixar-se adormecer / na ilusão de quanto existe, // o desejo de viver / já não tem asas; e a vida / dá 
vontade de morrer,//por não poder ser vivida / como o desejo a sonhava... Sinto-me exausta, vencida: // quanto da vida esperava, ou pedia à vida má, / sempre a vida mo negava! /E se a vida nunca dá / quanto o desejo lhe pede, / - pra quê viver? não será // bem melhor morrer à sede? (LARANJEIRA, 1993, p.162-163)

Este discurso da alma, se manifesta um desencanto absoluto, está plenamente de acordo com a necessidade que o poeta manifesta de projetar no real um ideal artístico. Porque oeu que responde tenta convencê-la a refugiar-se num compartimento que renega o contacto com os outros e que funciona, bem ao modo do extremismo definido por Ortega y Gasset, como solidão iludida:

Oh alma, tu sabes bem: // a loucura é desejar / e pedir à vida injusta / o que ela não pode dar... // Se é a vida que te assusta /desse modo, alma suicida, /desprende-te! Que te custa // ser livre, sem ver a vida, / nem a terra podre? Goza / de ver-te incompreendida, // de ver-te só! e, orgulhosa, /vive em ti, alma impotente! /Se a ventura é duvidosa, // e se a vida é triste e mente, /porque a miséria a invade, / tu, minh'alma, sê contente, // sobe e vai! Pela verdade, / renunciaste a fruir / a paz da felicidade (LARANJEIRA, 1993, p.163-164).

É neste contexto que o desejo de ascensão - que em Laranjeira dará particular relevo ao motivo das "asas" - se identifica com uma oposição à felicidade e com um desejo quase masoquista de consumição do eu, semelhante ao de Ícaro, e que conduz necessariamente à queda: "oh, alma, vai! Alevanta // pra verdade o pensamento! / - como essa águia ambiciosa /que sente um deslumbramento // da luz do sol, e, ansiosa, /pra o sol as asas conduz, /e vai e sobe, orgulhosa, // té cair ébria de luz!” (LARANJEIRA, 1993, p.164-165). A alma reage, exibindo as consequências dessa atitude irrefletida e condenando, por acréscimo, quer a tendência do sujeito para criar um mundo ilusório no qual, como observou Nuno Júdice, se encarava como um deus, quer o excesso de ambição do Homem que deseja fazer o mundo à semelhança do seu orgulho:

Tive asas de águia, com ânsia / de ar, de espaço, de voar / e de ir além da distância // que se abrange com o olhar, /quando tinham fé na vida / e a fé mas pôde levar... // Mas a ambição insofrida / de ir mais além -me perdeu: / pela ambição impelida, /tentei escalar o céu, /e tal céu não existia... / Havia-o criado eu // nesta louca fantasia, / em horas de aspiração... /Crendo, porém, que subia, //despenhava-me. Homem vão, / tentei ser Deus... e Deus era / a minha própria ambição! //Deus, o Deus que eu pretendera / destronar, nunca existira: /era uma louca quimera, // uma 
orgulhosa mentira, / que o homem criara, ufano, na mesma hora em que sentira // o desejo, monstro, insano, / de prender todo o universo / na mão do destino humano //Como se um génio perverso / me impelisse pra desdita, /ou malfadasse no berço, // herdei a ambição que incita / a ser Deus, ou sucumbir / nessa jornada infinita... //Pobre ambição! Que é subir? /é ser Deus (que não existe)? / O destino era cair, // se nessa loucura triste / de aguardar Deus (ou de o ser) todo o destino consiste! (LARANJEIRA, 1993, p.168-170).

No final deste diálogo a sós - como não poderia deixar de ser tendo em conta que, à sua maneira, as duas vozes refletem sobre a possibilidade e o fracasso de um isolamento ascensional e da sua queda, cuja responsabilidade é sempre pessoal, mesmo quando desejando ser exemplar de toda a busca humana pela Verdade - o sujeito acaba por se render à evidência, condenando-se a acompanhar "a vida rolando // na ilusão de quanto existe" (LARANJEIRA, 1993, p.176). Não cremos, porém, que exista uma inflexão significativa da postura deste sujeito, como considera Seabra Pereira, que vê na voz inicial com que se dirige à alma o reflexo de "um poeta à partida optimista e vitalista" (PEREIRA, 1977, p.42). Observação que, aliás, já Bernard Martocq efetuara no seu abrangente estudo da obra do poeta de Espinho, ao reconhecer neste sujeito sobretudo "unoptimismerelatifoù se mêlentrenoncementetvolontéprométhéenne” (MARTOCQ, 1985, p.493).

O poema "Comigo (diálogo com a minha alma)", além de estruturar exemplarmente os temas a partir dos quais evoluirá toda a recolha, expõe também as duas vozes que se digladiam em muitas passagens do Diário intimo, em que se reconhecem o desejo de converter a existência numa obra de arte e de escapar ao quotidiano e a consciência do fracasso desse intento. O conflito dá-se na consciência de um sujeito que procura convencer-se da sua superioridade para se satisfazer com as possibilidades que ela lhe traz, de modo a observar tudo de um plano criticamente superior (o ideal de ascender ao patamar divino para dali controlar as personagens humanas com que convive, portanto) mas que não consegue evitar sentir-se em absoluta falência. Logo no começo do Diário, são bastante evidentes o afastamento aristocratizante face ao público de uma das suas peças de teatro e a identificação entre a obra e a vida:

Isto em mim, afinal, é um orgulho desmedido. Para mim o público é a esfinge com orelhas de burro, e a celebridade - o manjar das vaidades triviais. Tolerar o público seria colocar-me abaixo de mim mesmo, abaixo do que eu penso de mim mesmo (...).Se o conhecimento do temperamento do artista não fosse indispensável 


\section{Desassossego}

DESASSOSSEGO 12 | DEZ/2014 | ISSN 2175-3180

DOI: http://dx.doi.org/10.11606/issn.2175-3180.v6i12p65-80

para o estudo e compreensão da obra de arte, valia a pena publicar os livros sem nome de autor. Mas onde existe aí o artista capaz de colocar-se fora da sua obra de arte, ou, como pretendia Flaubert, pairar por cima dela como o espírito de Deus por sobre as águas? (p.243)

Os lamentos dolorosos relativamente à incapacidade de a vida expressar adequadamente esse ideal elevado de um sujeito permanentemente insatisfeito repetir-se-ão ao longo das páginas das agendas, como documentam alguns exemplos: "Por que hei-de eu querer que a vida seja uma obra de arte composta à minha fantasia e não uma comédia cruel e dolorosa?" (p.244); "Por que não há-de a vida estar cheia de coisas formosas da formosura moral? (p.248); "Se eu estou farto de saber que o mundo não pode ser belo como a nossa fantasia o sonha, para que me hei-de perturbar com a imperfeição das almas?" (p.253); "No mundo só havia de haver coisas belas e coisas boas - ...e verdadeiras. - Tanto não digo: uma ilusão que se não desfaz, praticamente, vale tanto como uma verdade. De mais o que é belo é sempre verdadeiro" (p.262-263); "Sinto um desânimo infinito. A vida parece-me ilusória até à hora amarga do desengano. E eu pergunto de que serve ter-se ilusões grandes e belas ilusões" (p.275). Está em causa um ideal de beleza impossível de alcançar pela vida real e pelas pessoas que nela se movimentam e que contactam com o sujeito, situação de que este procura convencer-se mesmo que tal o perturbe. Observa justamente Eugénio Montoito:

Manuel Laranjeira, como toda a sua geração de «românticos» (mesmo quando declaravam não o ser), orienta a sua vida na procura do expoente do absoluto. Mas, ao encontrar-se perante a realidade que o envolve, sem poder renunciar nem afastar-se desse mundo, responde com a aparição do conflito, encaminha a discussão para a insolubilidade e finaliza pela dramatização do fracasso, da derrota, da desilusão, enfim, do desaparecimento de tudo aquilo que representava a presunção dos ideais (MONTOITO, 2001, p.82).

Esta questão cruza-se com outros dois aspectos, a sensação de isolamento por não ser devidamente compreendido e a perceção de todos os outros enquanto personagens de um grande drama do qual, como observa Júdice, só o próprio está consciente e que portanto nunca poderia corresponder às suas ambições (JÚDICE, 1998, p.104). É daí que nasce esse desejo de "voar da terra baixa e triste até às alturas imaculadas" (p.248), essa azeda percepção dos outros como "uma colecção de imbecis" (p.251) que vai acumulando, 
esse olhar universalizante segundo o qual "tudo me parece pardo e ordinário" (p.248), essa "raiva surda, uma fúria de romper com tudo e ser só - só, absolutamente só, como Deus" (p.259), solidão que por momentos fortalece o sujeito, por lhe oferecer "uma esperança de que poderei um dia libertar-me de todos os homens e ficar só comigo" (p.261). É de facto muito radical a perceção que esta identidade poética tem dos contactos com as outras pessoas como um grande espetáculo ao qual assiste representando também o seu papel. Avoluma-se uma interioridade em que se projetam todos os outros, conforme o próprio observa ao responder a uma das múltiplas tentativas de Augusta, mulher com quem se relaciona na época em que decorre a escrita do Diário Íntimo e cuja peculiaridade analisaremos posteriormente, para compreender a distração permanente que a vê "dentro de mim" (p.263).

Essa vivência espetacular das relações humanas assume diferentes facetas, surgindo: como tentativa inglória de o sujeito se distrair ("Para distrair-me ponho-me a namorar a $\mathrm{H}$. Ela honradamente deixa-se namorar. Toma atitudes românticas, de melancolia e desilusão, e inquietude. $\mathrm{O}$ espetáculo diverte-me por alguns minutos. Acabo de enfastiar-me com a sentimental comédia”, p.265); como moderada compensação para a desilusão face à vida e aos homens ("Unamuno é uma alma perturbada, um espírito dramático (...) - e estes conflitos interiores são para mim um espectáculo emocional, raro... Tenho a sensação de que ainda há quem viva a vida, e que a vida não é a mesma farsa pelintra e ordinária de todos os dias...", p.272); e, entre outros, como expressão da incapacidade de se interessar seja pelo que for (“O espectáculo de uma alma é o mais curioso dos espectáculos. E quando essa alma é de mulher o espectáculo redobra de interesse... se eu pudesse interessar-me, claro", p.290). Persiste, definitivamente, essa consciência omnisciente e isolada - "eu observo tudo e sinto uma sensação de desconsolo infinito e de aborrecimento sem termo por quanto existe. Ver tudo e compreender tudo! - que triste coisa!” (p.284).

Em outros poemas de Comigo, estão presentes alguns aspectos relevantes para a leitura dessa duplicidade entre sensação de saciedade (e portanto incapacidade de se surpreender com as coisas e de desejar conviver normalmente com os outros) e um desejo infindável de um qualquer ideal salvador. Um dos poemas chama-se, precisamente, "A 
saciedade dos insatisfeitos"4 (p.187) e trata justamente esse círculo vicioso entre o contacto com os outros, que poderia constituir uma experiência vitalista, e a sensação de incompletude e insatisfação que emerge sempre. É esse "desgosto dos sempre insatisfeitos, / - ao ver que amaram tanto (e tanto em vão) / e após horas e horas de paixão / só gozaram prazeres imperfeitos".

Absolutamente dominado pelo extremismo de desejar nas coisas uma perfeição impossível dada a condição humana e a própria incapacidade de fazer coincidir os sonhos com que insuflou os outros com aquilo que de facto eles representam, resta-lhe apenas "o tédio horrível /de saber que é inútil, desprezível, /a ventura que a gente concebeu // nessas horas de febre visionária: e o desgosto de quem reconheceu / quanto a vida ideal... é ordinária". Laranjeira dá uma tonalidade pessoal a essa consciência típica do individualismo artístico moderno, que faz do Poeta um ser iluminado capaz de idealizar mundos alternativos, nas tais "horas de febre visionária", e que nunca consegue adequar-se aos outros nem ao mundo supostamente real em que se movimentam. Está presente no tríptico de sonetos "A sós" (p.198-199), também, a sugestão (tão típica por exemplo em António Nobre) do desabar de um mundo ideal identificado com os "castelos vãos" que "meu coração / fundou no vento incerto" e que estão agora "desfeitos em ruínas e poeira, /ei-los todos dispersos pelo chão!...” E, uma vez mais, a abdicação - aqui identificada com o “despertar", adequando-se à leitura moderna da poesia como produtora de um mundo onírico alternativo - surge como solução, num conformismo de esteta desiludido: "Que remédio senão despertar, /se tudo quanto existe é imperfeito? (...) //Porque há-de a fantasia enfebrecida / buscar a perfeição de quanto existe /e encher de sonhos vãos a nossa vida? //se é por isso que somos desgraçados, /por sonhar tanto e em vão”. Algo que não é incompatível com aquele último vestígio de orgulho que o poema "Blasfémia inútil (à margem do 'Génesis')" identifica com a possibilidade de triunfar sobre o Criador abdicando da própria vida: "Alma rebelde, suicida, /seja a Obra maior que o Criador: /sê maior que Deus - despreza a vida...” (p.192). Sendo a vida, o mundo, os outros e o próprio eu produtos de um desengano infindável e irresolúvel, a única forma de triunfar será a entrega à aniquilação absoluta, simultaneamente concretização e resolução dessa natureza poética marcada por uma espécie de maldição.

\footnotetext{
${ }_{4}^{4}$ Tendo em conta que estes poemas de Comigo são muito menos longos que o poema homónimo, ocupando normalmente apenas uma página, indicaremos a página logo depois do título, remetendo para ela as citações subsequentes.
} 
Estende-se essa consciência do fracasso próprio de todas as crenças e possibilidades da vida à experiência amorosa, como não poderia deixar de ser. Porque, à semelhança de todas as outras questões, também a vivência do amor se deixa contaminar pela megalómana presença de um íntimo ideal impossível de concretizar por qualquer mulher real, suscitando novamente um apelo à desistência. $\mathrm{O}$ amor permanece condenado a uma cisão entre o desprezo e a superioridade masculina e a necessidade de confrontar as várias personagens femininas com que se relaciona (no Diário Íntimo é uma presença muito relevante) com a obsessão de que elas o abandonaram, traíram ou não sentirão a sua falta depois da morte. No poema "Palavras ao meu coração" (p.191), apela àquele que representa simbolicamente, na tradição lírica, a emotividade e o sentimento amoroso: "Renuncia! Se tudo quanto existe, / é mentiroso, e só nos faz descrer, / - não vale a pena amar, pra quê correr / atrás de sombras vãs, coração triste?” E sugere como alternativa, uma vez mais, a vertigem ascencional solitária: "Não querem entender-te, coração, /...não podem entender-te, quando tentas / erguer as pobres asas desse chão... // Queres pairar em regiões mais puras? /Vive acima da terra e das tormentas, / - sozinho como as águias nas alturas...”. Em "Carta a ninguém” (p.189), essa sensação de impossibilidade plena do amor é identificada com o desengano, que, como observa Martocq, faz parte da gradação decrescente que implica também o "descrer" e o "desamar" (Martocq, 1985, p.506). Fica expressa nesse poema a noção de que existem duas formas de amar, a do sujeito e a da destinatária (inexistente ou universal, podendo o título ser lido como "carta sem destinatário" ou "carta a ninguém em particular"), inconciliáveis: "Não tornes a queixar-te mais de mim! /Eu não te posso amar: amar assim, /como os outros... não sei... era um engano... // Foi bem maior que a tua a minha dor: / tu sofreste o desamor, / mas eu, filha, sofri - o desengano...”.

No Diário Íntimo, o amor é considerado de acordo com esta noção de desengano preferencialmente por via das várias facetas que o relacionamento com Augusta vai conhecendo, mesmo quando se apresentam outras mulheres, quer sejam antigas amantes, quer apenas pretextos para que o sujeito reflita acerca do amor, da fidelidade, da sensualidade feminina e das incongruências da moralidade conservadora - algo que ganha peso sobretudo tendo em conta que Augusta é marginalizada por ser sua amante. Este relacionamento tem alguma peculiaridade uma vez que o sujeito parece identificar na rapariga algo que a aproxima um pouco de si e da sua sede irreparável - "Pobre alma! Também ela tem loucura de absoluto! Também ela sofre da loucura ansiosa do eterno!" 
(p.246) - e lhe concede o direito de partilhar as suas deambulações meditativas, novamente concordantes com a metáfora do voo impossível - "Saímos e caminhamos à toa, para diante de nós, sem destino como duas almas sozinhas, como duas aves nostálgicas das alturas inacessíveis" (p.259). Augusta chega a ser encarada como refúgio ou potenciador de um encontro consigo, eterno destinatário de todas as suas contemplações - "Hoje o dia dei-o à Augusta, quer dizer, gastei-o comigo, a esquecer-me das misérias da vida e a viver nas regiões exaltadas da fantasia" (p.260). Identificação que nunca o impede de ser muitas vezes propositadamente cruel, como admite: "De facto creio que a estava ferindo - no coração... Só para saber se ela tinha coração. O meu eterno egoísmo feito de crueldade" (p.249). Isto porque Augusta também não consegue (mas nem Unamuno, personalidade do universo literário, o conseguiu) escapar a essa obsessão que impede uma vivência feliz em nome de uma construção poética ideal da qual todos participam, mesmo à custa do sacrifício do sujeito. É evidente a consciência de que aquela relação particular é alvo de uma dramatização típica da forma como encara o Amor:

Por que dramatizo eu este amor com a Augusta? Por que não háde ser isto um amor banal com os outros? Ou será para mim o Amor aquele «engano cego da alma», de que falava o poeta? Terei eu como os outros diante dos olhos uma tela de ilusão e encanto... haverá para mim aquele espelho mágico que Mefistófeles mostrava ao doutor Fausto, quando queria adormecê-lo na ilusão do Amor... E por que havia eu de ser privilegiado? (p.264-265).

A dada altura, surge uma reflexão sobre o que permite àquela relação durar tanto tempo, na qual as fronteiras entre realidade e representação são equacionadas:

Tenho passado o dia a pensar se estes amores com a Augusta serão amor, se comédia, e reconheço que há um pouco de tudo. Inclino-me a crer que seja comédia e comédia triste, porque eu represento nela um papel mudo. Mas reconheço também que a imobilidade não dura sempre e se isto fosse uma triste comédia apenas, eu não a teria suportado tanto... E quem sabe? às vezes, quando se está calado, é que se é mais comediante... (p.298).

A dramatização é tão sentida intimamente pelo sujeito - como o próprio Diário Íntimo, enquanto conjunto de fragmentos remetendo para ocasiões e personagens reais elaboradas literariamente, documenta em si mesmo - que de certa forma Augusta passa a existir dentro dele, a pertencer-lhe, numa clara expressão de superioridade que tem muito a ver com o ideal de fazer corresponder o sujeito empírico ao Autor e este a Deus: "Trago-te 
dentro de mim... Fazes parte de mim, como o meu braço, como o meu pensamento. Tu já não és tu: és uma parte de mim mesmo" (p.267). Friamente, esta perceção alarga-se também ao campo dos sentimentos e da própria sexualidade:

A Augusta começa a farta-se de mim, vejo-o. Sinto a comoção estranha de que vou ser, de que estou sendo esquartejado. E depois que importa? Quase sinto uma alegria dolorosa de lembrarme que ela se pode cansar de mim. Aquela mulher, aquela carne que eu possuí e gozei, aquela alma que foi minha - há-de ser de outro? Não, o que eu possuí e gozei foi a minha ilusão e essa é minha. O corpo dessa mulher e a sua alma goze-os quem quiser. $\mathrm{Na}$ verdade o que foi meu foi a minha ilusão apenas. E serei livre! (p.268).

Todo o amor é permanentemente adaptado aos interesses desse tirânico sujeito que várias vezes refere a presença de um "demónio interior" que assume o controlo. Mesmo nos episódios concretos de interação emocional e física paira a certeza de um narrador que tudo mancha com a ironia, negando realidade às coisas para lhes dar a aura de uma ficção ou mesmo de um trabalho laboratorial de teste à natureza humana: "E beijo-a, beijo-a doidamente, estonteado. Depois vem uma crise de prazer brutal, uma epilepsia de alguns minutos, inconsciente, animal. Depois... - depois «la commedia e finita»" (p.273). Estamos em presença dessa característica peculiar do Diário Íntimo que Seabra Pereira tão bem sintetiza:

$\mathrm{Na}$ ambiguidade do seu estatuto comunicacional, cuja plataforma é a indistinção da persona de Laranjeira como autor empírico/autor textual/narrador autodiegético e, portanto, protagonista (herói e anti-herói) da trama romanesca e psicologista (com Augusta e outras personagens secundárias), o Diário Íntimo promove uma situação de leitura em que, sem perder valor como documento humano (segundo a programática do género diarístico no espaço autobiográfico), pode actuar também como narrativa ficcionada (PEREIRA, 1993, p.24).

Este romance entre Laranjeira e Augusta ocupará, de resto, parte muito considerável das páginas diarísticas, a ponto de Martocq dar um lugar central ao sentimento amoroso no quadro desta visão aniquiladora do real típica do discurso íntimo: "Amour de Dieu,amour de l'autre, amour de l'Homme, toutemoraledubonheur se fondesurcesentiment par oùl'hommeéchape à lui-même et à sasolitude. Le journal intime, au contraire, l'y ramène, et l'amour n’y est présent que pour être nié” (MARTOCQ, 1985, p.65). São muitos os exemplos nos quais Laranjeira nega qualquer conteúdo a esse amor, para além do 
cumprir de um certo ritual que poderia culminar na obtenção da felicidade que o condenaria a deixar de ser livre. Ainda assim, existe genuíno interesse nessa ligação, mesmo que para a encarar de acordo com os estereótipos românticos desprezados: "Noite de amor, intensa, passional. A comédia sentimental e piegas atinge o seu interesse supremo" (p.278). A reação bipolar face a uma das muitas promessas de desfecho daquele amor é muito significativa, dividindo o eu entre um lado que parece ficar aliviado e outro que percebe o significado dessa conclusão em termos de condenação da felicidade:

Esta liberdade suprema custou-me a felicidade... Por isso é horrivelmente saborosa. Saio, vagueio à toa, como alguém que não sabe o que há-de fazer de tanta felicidade. Ao cruzar uma rua, sinto-me agarrado pela Augusta trémula, perdida... - Vem comigo. Depressa! senão caio morta na rua. - E eu, sem uma palavra, vou. Adeus, liberdade, estou preso outra vez (p.283).

Existe de facto uma estranha contradição entre as várias situações em que o narrador-personagem medita acerca do esfriar daquele relacionamento e parece querer perceber em Augusta os sinais dessa mudança, antecipando mesmo a indiferença que se seguirá e, no limite, comentando o conformismo despreocupado dela perante a sua doença e a sua morte, e casos em que o desprezo por ela é demasiado gritante, coincidindo com a idealização de um cenário de comprazimento face à absoluta humilhação pública da amante:

Com que então todos me acham alegre? Ainda bem! ainda bem que só eu sei a causa desta tristeza mortal. E que horrível desejo, que imoral, que perverso desejo eu sinto de ser rico, muito rico para fitá-la, com desprezo e carinho, e dizer-lhe:

- Toma, Augusta, toma dinheiro, muito dinheiro - em paga das horas de esquecimento, das ilusões que me deste. Goza, mulher, goza a tua humilhação. Goza-a e deixa-me gozar o meu desprezo... (p.292).

A própria Augusta tem muitas vezes consciência do muito que os separaria irreversivelmente, fruto do abismo entre um homem de cultura e uma mulher simples, que não consegue alcançar os voos perdidos a que ele se dedica. Desencontro incontornável quando esse sujeito masculino sofre, essencialmente, de uma consciência exacerbada e excessiva de si e da sua singularidade intelectual e artística:

Não imaginas como sofro quando penso que te deves sentir sozinho, sem ninguém que te compreenda, e quando me lembro 
que te não posso acompanhar.(...) De resto foi hoje um dia em que eu mais vivi dentro de mim. A pobre rapariga tinha razão ontem: há horas em que ela me não pode acompanhar: sou só, só” (p.299).

Parece-nos, tendo em conta os aspectos que abordamos ao longo desta reflexão, que Laranjeira partilha, dentro do seu universo particular e dos condicionamentos inerentes à doença de que padeceu constantemente e que arruinou a sua percepção da realidade, de uma concepção do Artista próxima daquela que os poetas de Orpheu, em particular Mário de Sá-Carneiro, identificaram com um desejo de evasão em ruptura com o real quotidiano e com as suas rotinas agressivas para a consciência poética com que encaravam a vida. O que permitirá que Manuel Laranjeira tenha necessariamente de ser recuperado numa reflexão acerca dessa tão rica transição entre a vivência finissecular do Simbolismo e do Decadentismo e as conquistas do Modernismo, nunca devidamente compreensíveis a não ser tendo em conta precursores de cujo panteão o poeta de Espinho merece indelevelmente fazer parte.

\section{Bibliografia}

Ativa

LARANJEIRA, Manuel. Obras de Manuel Laranjeira. Lisboa: Asa, 1993.

\section{Passiva}

CAMUS, Albert. O Homem revoltado. Trad. Virgínia Motta. Lisboa: Livros do Brasil, 2003.

JÚDICE, Nuno. "Manuel Laranjeira: o eu conflitual". As Máscaras do poema. Lisboa: Aríon, 1998, p.101-108.

MARTOCQ, Bernard. Manuel Laranjeira et son temps (1877-1912). Paris: Fondation Calouste Gulbenkian - Centre Culturel Portugais, 1985.

MONTOITO, Eugénio. Manuel Laranjeira e o sentimento decadentista na passagem do século XIX. Lisboa: Heuris, 2001.

ORTEGA Y GASSET, José. "Lección IX. Sobre el extremismo como forma de vida". Obras Completas, vol. V. Madrid: Alianza, 1983, p.107-121.

PEREIRA, José Carlos Seabra. Decadentismo e Simbolismo na Poesia Portuguesa. Coimbra: Coimbra Editora, 1975.

Colóquio-Letras, no 40, p.41-47, 1977.

Para uma análise de «Comigo» de Manuel Laranjeira.

"Posição literária de Manuel Laranjeira" inDo Fim-de-Século ao Tempo de Orfeu. Coimbra: Almedina, 1979, p.41-61.

"Laranjeira - o ódio amante dos desiludidos" in

LARANJEIRA, Manuel. Obras de Manuel Laranjeira. Lisboa: Asa, 1993, p.7-28. 